\title{
Corporate Bankruptcy Measurement and Prediction: Evidence from Publicly Traded US Firms
}

\author{
Hong Long Chen \\ Department of Business and Management \\ National University of Tainan \\ No. 33, Sec. 2, Shu-Lin St., Tainan 70005, Taiwan
}

\begin{abstract}
We develop a bankruptcy classification model combining financial ratio analysis, measurement theory, and logistic analysis from a sample of 258 bankrupt and non-bankrupt public companies in the United States. Transformed financial variables are developed to a bankruptcy classification measurement model using the confirmatory factor analysis, which is then refined to a four variable, logit bankruptcy model. The result shows that the model possesses high classification accuracy and relatively small differences in classification rates between in-sample and out-of-sample as compared to industry-relative analysis. As such, our findings help managers more accurately estimate bankruptcy risk and thus, have a better opportunity to take corrective actions early, enhancing corporate financial sustainability.
\end{abstract}

Keywords: Bankruptcy; Financial failure; Performance measurement; Forecasting; Logit models

\section{Introduction}

This paper presents another model on business bankruptcy that uses financial variables, measurement-theory, and logistic analysis as its core. The central attribute of our model is its use of improved stability of financial variables over timeas explanatory variables in the derivation of a logit function from a bankruptcy performance-measurement model.

The inclusion of the improved stability of financial variables in the bankruptcy analysis enhances the ability of the logit function to predict corporate bankruptcy. Our model classifies out-of-sample companies into bankrupt and non-bankrupt groups with $94.59 \%$ accuracy one year before bankruptcy. This paper improves the previous bankruptcy work principally in its longer study period and larger bankruptcy sample size, the inclusion of stable explanatory variables as well as the measurement-theory type of analysis.

This study proceeds as follows. Section 2 reviews related studies. Section 3, "Approach and methods of analysis," describes the sample data and methodology of this study. Section 4, "Research results," depicts the measurementtheory model development, classification model-building and validation. Section 5, "Conclusion," summarizes the research.

\section{Previous Research}

Whilst the idea of performance relates to how successfully an organization attains objectives or executes a strategy (Otley, 1999), it is relative performance that stands at the core of the literature on predicting corporate failure and bankruptcy (Foreman, 2003). Not surprisingly, numerous academics and practitioners (e.g., Altman, 1968; Altman et al., 1977; Beaver, 1966; Charitou et al., 2013; Ohlson, 1980) conduct extensive studies and apply sophisticated mathematical methodologies to develop bankruptcy classification models through examining and identifying the determinants of corporate bankruptcy.

For example, Charitou et al. (2004) investigate the incremental information content of operating cash flows in forecasting bankruptcy on the basis of logistic analysis and conclude that cash flow, profitability, and financial leverage variables are significant in the failed and nonfailed classification model. Pompe and Bilderbeek (2005) employ multivariate discriminant analysis to examine the predictive ability of financial ratios during the successive phases before bankruptcy, as well as the relationship between the age of a firm and the predictability of bankruptcy. They conclude that every ratio investigated has some predictive power. Kim and Nabar (2007) discover that although the likelihood of bankruptcy decreases before bond upgrades, the likelihood increases both beforeand after bond downgrades.

Subsequent work by Agarwal and Taffler (2008) uses multivariate discriminant analysis to compare market-based and accounting-based bankruptcy prediction models, and concludes that little difference exists in their predictive ability. Concurrently, Arena (2008) investigates banking crises in East Asia and Latin America and concludes that bank-level fundamentals such as asset quality, solvency, and liquidity significantly affect the likelihood of collapse for these banks. 
Li and Miu (2010) combine Altman's (1968) Z-score model and Merton's (1974) market-based model to develop a hybrid bankruptcy prediction model, and claim their model are superior to conventional logistic models. Kwak et al. (2012) propose a multiple criteria linear programming (MCLP) method to predict bankruptcy based on preselected 13 financial ratios. They compare their MCLP method to both multiple discriminant analysis and logistic analysis, and conclude that the MCLP method is a viable alternative for bankruptcy forecasting. Charitou et al. (2013) examine the empirical properties of the theoretical Black-Scholes-Merton (BSM) bankruptcy forecasting models, and conclude that a market-based measure of volatility estimated directly from monthly firm value returns possesses relatively high forecasting accuracy.

Subsequent work by Gavurova et al. (2017) evaluates four bankruptcy classification models, which are developed from various financial ratios, to determine the most suitable model for predicting bankruptcy in Slovak. They conclude the index IN05 model outperforms others in the Slovak business environment. More recently, Akbar et al. (2019) employ hierarchical linear mixed model analysis to examine the relationship between bankruptcy risk and the company life cycle with a set of financial ratios and economic variables. Based on a sample of 301 companies from 12 different industries, they conclude that companies suffer a relatively high level of bankruptcy risk during the start-up, growth and decline stages. They hence suggest managers to incorporate the company life-cycle effect into financial planning and decisions to achieve financial stainability.

Although numerous academics and practitioners (e.g., Akbar et al., 2019; Gavurova et al., 2017; Kim and Nabar, 2007; Kwak et al.,2012; Li and Miu, 2010)conduct extensive studies to develop bankruptcy-prediction models, relatively few explore the stability of financial variables over time. The inclusion of the stability of financial variables in the bankruptcy analysis is critical, as it improves considerably the ability of classification models to predict bankruptcy (Dambolena and Khoury, 1980).In this study, we propose a simple formula to stabilize financial variables and thus, develop a relatively stable logit bankruptcy function over time.

\section{Approach and methods of analysis}

\subsection{The data}

Our sample of bankrupt companies includes companies that encountered bankruptcy or liquidation events as defined by the COMPUSTAT database. Because of data accessibility, our study period is limited between 1986 and 2008, covering 23 years. We exclude companies that do not have complete data sets available on the COMPUSTAT database, resulting in 129 companies included in bankruptcy. These bankrupt companies range in size from $\$ 0.1$ million to $\$ 29,985.5$ million in assets.

To isolate key variables that distinguish bankrupt from nonbankrupt companies, we select a sample of nonbankrupt companies from COMPUSTAT to match the bankrupt companies. The nonbankrupt companies have the same North American Industry Classification System (NAICS) code, nearly equal average asset size, and complete data sets available for the same year as the matched bankrupt firm one year before bankruptcy.

The 129 nonbankrupt companies range in size from $\$ 0.2$ million to $\$ 29,474.5$ million in assets. The average sizes of the bankrupt and nonbankrupt firms are $\$ 452.8$ million and $\$ 519.4$ million, respectively. The result of a t-test further confirms astatistically insignificant difference between the means of the bankrupt and nonbankrupt firms witha p-value of 0.81 .

We compute the financial variables and industry averages using data from COMPUSTAT. To obtain an industry average that is comparable across industries, we use two-digit NAICS codes. Companies with the same first twodigit NAICS code are classified in the same industry.

The 129 firms come from 14 sectors, including mining, construction, manufacturing, retail, transportation and warehousing, information, finance and insurance, real estate and leasing, professional, scientific and technical services, administrative and support, waste management and remediation services, and accommodation and food services. The 14 sectors include 2,613 companies.

The final data sets were split into two subsamples: the in-sample(ex-post) data and the out-of-sample (ex-ante) data. We use the in-sample data to build models; the data includes information for 184 equally matched bankrupt and nonfailed companies from 1986 to 1995, covering 10 years. We use the out-of-sample data, composed of 74 equally matched bankrupt and nonfailed companies between 1996 and 2008, covering 13 years, to study the predictive ability of the models.

\subsection{Variables and analysis}

Based on an extensive review of the literature and in an effort to generate a more comprehensive assessment, we include 62 financial variables that are potential bankruptcy determinants. The 62 variables encompass six different aspects of financial conditions or operating results, including cash flow, capital structure and solvency, short term liquidity, profitability performance, operating performance, and market. 
Cash Flow consists of nine financial variables (see Table 1). The representative studies are Altman et al. (1977), Beaver (1966), and Platt and Platt (1990). Sample variables are cash flow to total assets, operating cash flow to sales, and operating cash flow to net income.

Table 1: Taxonomy of financial variables as bankruptcy-predictor attributes, Kolmogorov-Smirnov tests, and Mann-Whitney $U$ tests

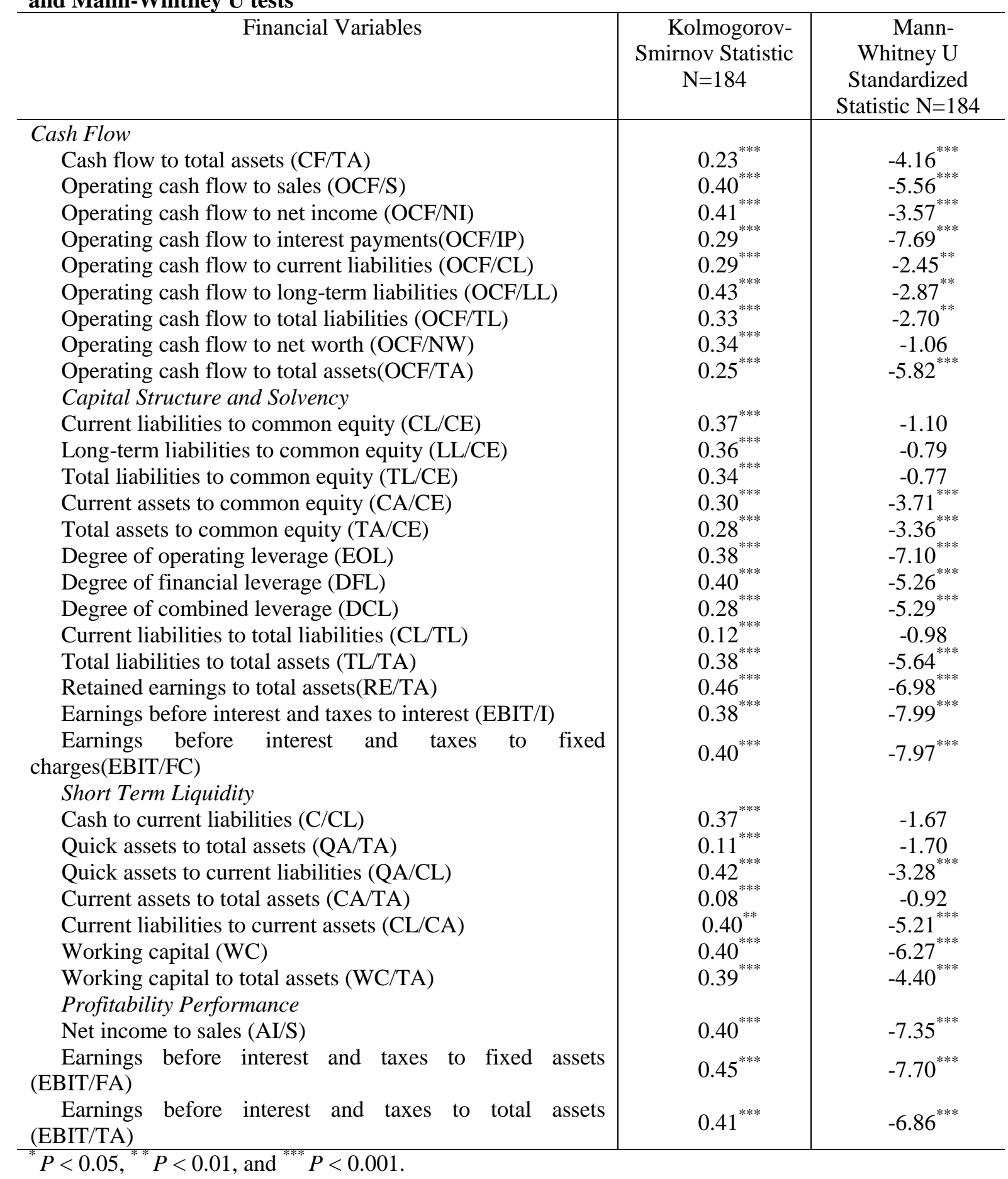

Table 1: Continued

Financial Ratios

\begin{tabular}{c|c}
$\begin{array}{c}\text { Kolmogorov- } \\
\text { Smirnov Statistic } \\
N=184\end{array}$ & $\begin{array}{c}\text { Mann- } \\
\text { Whitney U } \\
\text { Standardized } \\
\text { Statistic N=184 }\end{array}$ \\
\hline $0.37^{* * * *}$ & $-6.53^{* * *}$ \\
$0.33^{* * *}$ & $-6.22^{* * *}$ \\
$0.46^{* * *}$ & $-4.11^{* * *}$
\end{tabular}


Income before extraordinary items to total assets(IBEI/TA)

Income before extraordinary items to current liabilities(IBEI/CL)

Income before extraordinary items to net worth(IBEI/NW)

Operating Performance

Sales to inventory $(\mathrm{S} / \mathrm{I})$

Sales to quick assets (S/QA)

Sales to current assets (A/CA)

Sales to fixed assets (S/FA)

Sales to total assets (S/TA)

Sales to current liabilities (S/CL)

Sales to total liabilities (S/TL)

Current liabilities to sales (CL/S)

Growth in gross income (GGI)

Growth in total liabilities (GTL)

Growth in accounts receivable (GAR)

Growth in inventory (GI)

Growth in fixed asset(GFA)

Growth in tangible assets(GTanA)

Growth in property, plant and equipment (GPPE)

Growth in total assets(GTA)

Market

Price-earnings ratio $(\mathrm{P} / \mathrm{E})$

Common dividends (CD)

Common dividends to outstanding shares (CD/OS)

Market value of common stock (MVCS)

Market capitalization (MC)

Market value of equity to book value of total debt (MVE/BVTD)

Market value of equity to book value of equity (MVE/BVE)

Market capitalization to total debt(MC/TD)

${ }^{*} P<0.05,{ }^{* *} P<0.01$, and ${ }^{* * * *} P<0.001$

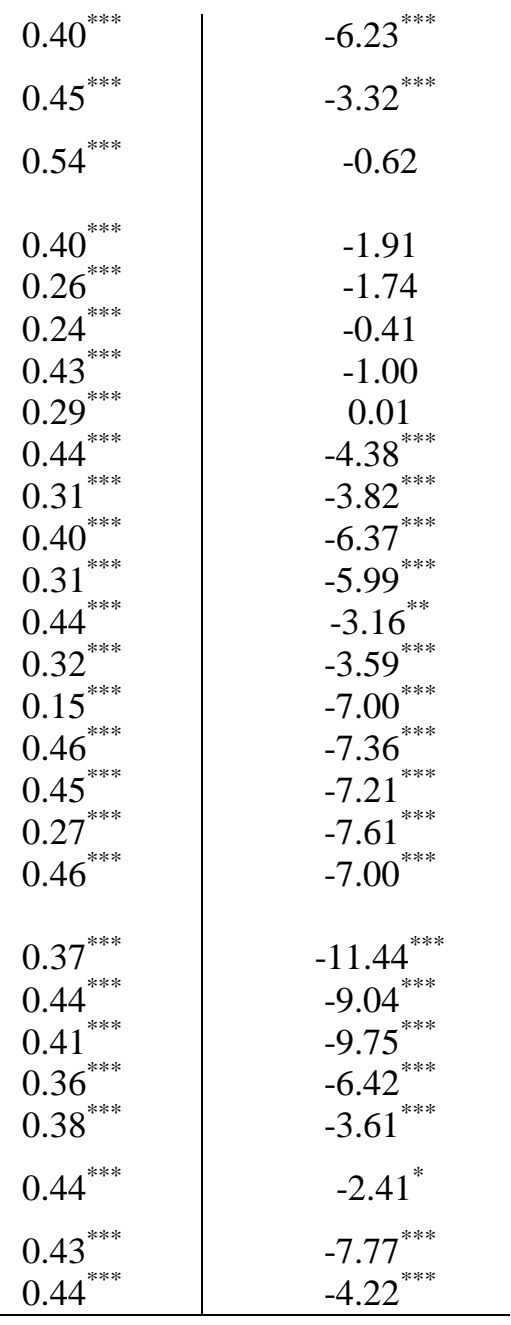

$-0.41$

$-1.00$

0.01

4.38

$-3.82^{* * *}$

$-6.37^{* * *}$

$-5.99^{* * *}$

$-3.16$

$-3.59^{* * *}$

$-7.00$

$-7.36^{* * *}$

$-7.21^{* * *}$

$-7.61^{* * * *}$

9.04

$-9.75^{* * *}$

$-6.42^{* * * *}$

$-3.61$

$-2.41$

$-4.22^{* * *}$

Capital Structure and Solvency is composed of 13 financial variables (Table 1). The representative studies include Altman et al. (1977), Charitou et al. (2004), Foreman (2003), and Ohlson (1980). Sample variables include current liabilities to common equity, long-term liabilities to common equity, and total liabilities to common equity.

Short Term Liquidity Performance is composed of seven financial variables (Table 1) based on prior research. The representative studies include Altman (1968), Altman et al. (1977), Beaver (1966),Li and Miu (2010), Ohlson (1980), and Platt and Platt (1990). Sample variables are cash to current liabilities, quick assets to total assets, and quick assets to current liabilities.

Profitability Performance is composed of nine financial variables (Table 1). The representative studies include Altman (1968), Altman et al. (1977),Beaver (1966), Charitou et al. (2004), Foreman (2003), Kim and Nabar (2007), $\mathrm{Li}$ and Miu (2010), and Platt and Platt (1990). Sample variables are net income to sales, earnings before interest and taxes to fixed assets, and earnings before interest and taxes to total assets.

Operating Performance consists of 16 financial variables (Table 1). The representative studies include Altman (1968), Altman et al. (1977), Beaver (1966), Charitou et al. (2004), and Li and Miu (2010). Sample variables include sales to inventory, sales to quick assets, and growth in gross income.

Market consists of eight financial variables (Table 1). The representative studies include Agarwal and Taffler (2008), and $\mathrm{Li}$ and Miu (2010).Sample variables include price-earnings ratio (basic), common dividends to outstanding shares, and market value of common stock.

Table 1 lists the taxonomy of financial variables, Kolmogorov-Smirnov tests, and Mann-Whitney U tests for one year prior to bankruptcy for 184 bankrupt and nonbankrupt companies. We use Mann-Whitney U tests for the 62 financial variables because the data are not normally distributed based on the results of Kolmogorov-Smirnov tests, which deem data abnormally distributed when the probability value is smaller than the threshold value of 0.05 .

As the table shows, a significant difference exists in the mean values of bankrupt and nonbankrupt companies for 48 of the 62variables in one year before bankruptcy. Significance of difference in means exists when the probability of the Mann-Whitney $U$ test is smaller than 0.05 . Therefore, based on the results of the Mann-Whitney U tests, we include 48 variables for further study. 
We use a twofold methodology to develop our bankruptcy classification model. In the first stage, we first propose an exponential function-based algorithm to transform the 48 financial variables. Based on the transformed 48 financial variables, we develop a bankruptcy measurement model based on the confirmatory factor analysis (Harrington, 2008). Items with an overall correct classification rate lower than $60 \%$ and standardized factor loadings smaller than 0.50 are deleted. Further deletion of a dimension's items for refining the measurement model is evaluated by means of repeated model fittings based on examining standardized loadings, interpretability, and content validity along with a minimum standardized root mean square residual (RMSR) procedure (Frohlich, 2002).

In the second stage, we conduct a multivariate logistic-regression analysis with backward elimination of the financial variables included in the bankruptcy measurement model to evaluate the redundancy of the variables used to predict corporate bankruptcy. Validation of the final bankruptcy model is by out-of-sample Type I (bankrupt firm sample) accuracy, Type II (nonbankrupt firm sample) accuracy, and overall correct classification rates.

\section{Research results}

\subsection{Analysis of stability after data transformation}

As there exists a great range of data in the 48 financial variables (e.g., from a negative working capital of $\$ 2,979.4$ million to a market capitalization of $\$ 6,317.4$ million), to reduce the variance in the data through data transformation becomes necessary. In addition, to make more sense of the 48 variables in relation to corporate bankruptcy prediction, where 1 is for bankruptcy and 0 is for non-bankruptcy, we propose to transform the 48 variables by the following exponential function-based algorithm so that their values range between 0 and 1 .

$T(X)_{i, k}=\exp \left(X_{i, k}\right) /\left(1+\exp \left(X_{i, k}\right)\right)(1)$

where $X_{i, k}$ is the $k$ th financial variable of the $i$ th firm. To examine whether $T(X)_{i, k}$ stabilizes the data, we propose the following hypothesis:

Hypothesis 1: The stability of the 48 financial variables is significantly improved subsequent to the $T(X)_{i, k}$ transformation.

Whilst the standard deviation (SD) and stander error (SE)show how much dispersion or variation from the average exists, SD and SE are commonly used as measures of volatility (instability) in finance (Dambolena and Khoury, 1980). Using data for one year prior to bankruptcy for the 184 bankrupt and nonbankrupt companies from 1986 to 1995, we use the SDsand SEs of 48 financial variables after transformation against those of 48 financial variables' industry-relative ratios (IRRs)to examine whether $T(X)_{i, k}$ results in better stability than IRRs. ${ }^{1}$ Namely, smaller $\mathrm{SD}$ and SE suggest less volatility and, thus, more stability.

Panels A and B of Table 2 report the Wilcoxon signed-rank test's results that confirm a significant difference in both the SDs and SEs between IRRs and $T(X)_{i, k}$ transformation with a $p$-value of $<0.001$, suggesting that $T(X)_{i, k}$ results in considerably smaller SDs and SEs, where the use of the Wilcoxon signed-rank test is justified by the fact that the data are not normally distributed based on the result of Kolmogorov-Smirnov tests. Therefore, we accept hypothesis 1 that $T(X)_{i, k}$ significantly improves the stability of the financial variables.

Table 2: Analysis of data stability after $T(X)_{i, k}$ transformation against industry-relative ratios (IRRs) using the in-sample data of 184 bankrupt and non-bankrupt companies

\begin{tabular}{lcccc}
\hline \multicolumn{1}{c}{ Source } & Mean & Minimum & Maximum & $\begin{array}{c}\text { Kolmogorov } \\
\text { Smirnov Statisti }\end{array}$ \\
\hline Panel A & 32.83 & 1.11 & 779.35 & $0.400^{* * * *}$ \\
SDs of 48 variables' IRRs & 0.19 & 0.07 & 0.43 & $0.212^{* * * *}$ \\
SDs of 48 variables after $T(X)_{i, k}$ transformation & & & & \\
Median SD difference between IRRs and after $T(X)_{i, k}$ transformation & & & & $0.40^{* * * *}$ \\
\hline Panel B & 2.42 & .08 & 57.45 & $0.21^{* * * *}$ \\
SEs of 48 variables' IRRs & 0.01 & .00 & .03 & \\
SEs of 48 variables after $T(X)_{i, k}$ transformation & & & & \\
Median SE difference between IRRs and after $T(X)_{i, k}$ transformation & & & &
\end{tabular}

\footnotetext{
${ }^{1}$ Previous studies (e.g., Altman and Izan, 1983; Izan, 1984; Platt and Platt, 1990, 1991) propose using IRRs to control for industry and time variations, they show considerably better out-of-sample classification results for bankruptcy models using IRRs.
} 
${ }^{*} P<0.05,{ }^{* *} P<0.01$, and ${ }^{* * *} P<0.001$.

4.2. Analysis of bankruptcy measurement model

Figure 1 depicts the final measurement model for bankruptcy classification, revealing those transformed financial variables ultimately retained for each performance dimension. The measurement mode is congeneric, which has five constructs that correlate with all other constructs

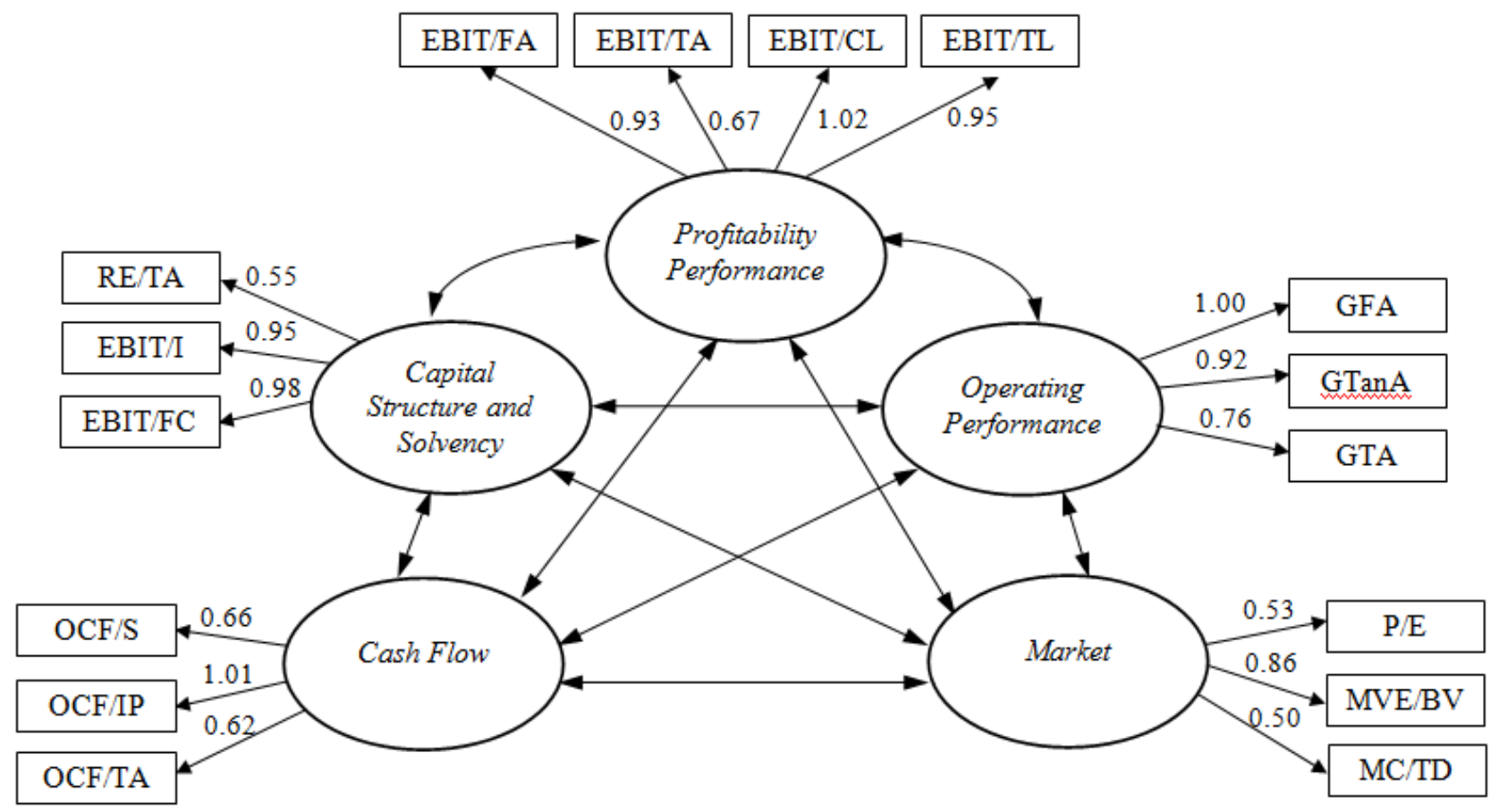

Figure 1: Performance-measurement model for bankruptcy classification

The standardized factoring loadings and composite reliability are used to evaluate the relative convergence among item measures. As Figure 1 shows, the factor loadings range from 0.50 to 1.02 and are significant at the $p<0.01$ level, suggesting the existence of convergent validity (Harrington, 2008). Further, whilst a composite reliability (CR) of 0.6 or higher indicates convergent validity (Kline,2010), the bottom of Table 3 shows that the respective CRvaluesof Cash Flow, Capital Structure and Solvency, Profitability Performance, Operating Performance, and Market are $0.74,0.74,0.81,0.75$, and 0.75 , confirming an adequate convergence for all the constructs.

In addition, we compare the average variance extracted (AVE) values for any two constructs with the square of the correlation estimate between the constructs to examine if discriminant validity exists. Table 3 shows that the AVE value of Cash Flow is 0.61that is greater than the square of the correlation estimate between Cash Flow and any of the other constructs, and likewise the AVE values of Capital Structure and Solvency, Profitability Performance and Operating Performance are all larger than the square of their respective correlation estimates. This indicates that any of constructs in the measurement model is able to explain more of the variance in its item measures than it shares with other constructs, supporting discriminant validity for the measurement model (Fornell andLarcker, 1981).

Table 3: Squared correlations, average variance extracted, and composite reliability of the bankruptcy performance-measurement model

\begin{tabular}{lrrrr}
\hline Variable & Cash Flow & $\begin{array}{c}\text { Capital } \\
\text { Structure and } \\
\text { Solvency }\end{array}$ & $\begin{array}{c}\text { Profitability } \\
\text { Performance }\end{array}$ & $\begin{array}{c}\text { Operating } \\
\text { Performance }\end{array}$ \\
\hline Cash Flow & 1 & 1 & & \\
Capital Structure and Solvency & 0.58 & 0.57 & 1 & \\
Profitability Performance & 0.45 & 0.09 & 0.04 & 1 \\
Operating Performance & 0.04 & 0.50 & 0.32 & 0.50 \\
Market & 0.32 & 0.72 & 0.81 & 0.81 \\
Average Variance Extracted & 0.61 & 0.74 & 0.81 & 0.75 \\
Composite Reliability & 0.74 & & & \\
\hline
\end{tabular}

The final analysis results of the measurement model suggest an adequate fit with the data. The model's NFI, CFI, GFI are 0.95, 0.92, and 0.97, respectively, which are higher than the threshold value of 0.90 suggested by Bentler 
(1990). The RMSR is 0.003 and the root mean square error of approximation (RMSEA) is 0.080, which are both smaller than the respective threshold values of 0.01 and 0.10 (Kline,2010).

\subsection{The bankruptcy model}

Using multivariate logistic-regression analyses with backward elimination of the transformed financial variables included in the bankruptcy measurement model, we assess the redundancy of the variables and develop optimal bankruptcy classification models from the 184 (in-sample) bankrupt and nonbankrupt companies between 1986 and 1995.The redundancy assessment of the variables was based on the statistical significance of estimated parameters andon a model's deviance and classification results. It was expected that the final set of variables in the model should be negatively related to bankruptcy. Table 4 reports the model-building results.

Table 4; Bankruptcy classification models created with multivariate logistic-regression analyses with backward elimination

\begin{tabular}{|c|c|c|c|c|c|c|}
\hline \multirow{2}{*}{$\begin{array}{l}\text { Variables and } \\
\text { Sources }^{\text {a }}\end{array}$} & \multicolumn{2}{|c|}{ Step1: Model 1} & \multicolumn{2}{|c|}{ Step 2: Model 2} & \multicolumn{2}{|c|}{ Step 13: Model 13} \\
\hline & Estimate & Chi-Square & Estimate & Chi-Square & Estimate & Chi-Square \\
\hline Intercept & $\begin{array}{r}535.7 \\
0\end{array}$ & 1.20 & $\begin{array}{r}552.0 \\
8\end{array}$ & 1.13 & $\begin{array}{r}339.8 \\
0\end{array}$ & 2.50 \\
\hline Cash Flow & & & & & & \\
\hline $\mathrm{OCF} / \mathrm{S}$ & -8.60 & 0.31 & -8.36 & 0.29 & -4.84 & 0.02 \\
\hline OCF/IP & 3.13 & 0.14 & 2.25 & 0.10 & & \\
\hline OCF/TA & $26.27^{-}$ & 0.24 & $18.5 \overline{6}$ & 0.17 & & \\
\hline $\begin{array}{l}\text { Capital Struct } \\
\text { and Solvency }\end{array}$ & & & & & & \\
\hline RE/TA & -2.72 & 0.09 & & & & \\
\hline EBIT/I & 5.25 & 0.60 & 4.84 & 0.65 & & \\
\hline $\begin{array}{l}\text { EBIT/FC } \\
\text { Profitability }\end{array}$ & -1.67 & 0.07 & -1.81 & 0.08 & -0.33 & 0.02 \\
\hline Performance & & & & & & \\
\hline EBIT/FA & -4.53 & 0.11 & -4.60 & 0.12 & & \\
\hline EBIT/TA & 31.64 & 0.34 & 24.40 & 0.27 & & \\
\hline EBIT/CL & 15.01 & 0.45 & 12.03 & 0.35 & & \\
\hline $\begin{array}{l}\text { EBIT/TL } \\
\text { Operating }\end{array}$ & 16.31 & 0.40 & 12.28 & 0.28 & & \\
\hline Performance & & & & & & \\
\hline GFA & 35.19 & 0.67 & 31.60 & 0.57 & & \\
\hline GTanA & $51.10^{-}$ & 0.98 & 49.83 & 0.93 & -5.40 & 1.20 \\
\hline $\begin{array}{l}\text { GTA } \\
\text { Market }\end{array}$ & 7.91 & 0.15 & 10.31 & 0.32 & & \\
\hline $\mathrm{P} / \mathrm{E}$ & $544.55^{-}$ & 1.22 & $561.37^{-}$ & 1.16 & $343.81^{-}$ & 3.64 \\
\hline MVE/BVE & -3.97 & 0.15 & -4.27 & 0.18 & & \\
\hline $\mathrm{MC} / \mathrm{TD}$ & 12.74 & 1.12 & 13.51 & 1.25 & & \\
\hline -2 Log likelihood & 17.07 & & 17.13 & & 23.08 & \\
\hline Nagelkerke $R^{2}$ & 0.97 & & 0.97 & & 0.96 & \\
\hline Type I Accuracy & $\begin{array}{r}97.80 \\
\%\end{array}$ & & $\begin{array}{r}97.80 \\
\%\end{array}$ & & $\begin{array}{r}97.80 \\
\%\end{array}$ & \\
\hline Type II Accuracy & $\begin{array}{r}100.0 \\
0 \%\end{array}$ & & $\begin{array}{r}100.0 \\
0 \%\end{array}$ & & $\begin{array}{r}100.0 \\
0 \%\end{array}$ & \\
\hline Overall Correct & $\begin{array}{r}98.90 \\
\%\end{array}$ & & $\begin{array}{r}98.90 \\
\%\end{array}$ & & $\begin{array}{r}98.90 \\
\%\end{array}$ & \\
\hline
\end{tabular}

${ }^{a}$ All financial variables are transformed by $T(X)_{i, k}=\exp \left(X_{i, k}\right) /\left(1+\exp \left(X_{i, k}\right)\right)$.

${ }^{*} P<0.05,{ }^{* *} P<0.01$, and ${ }^{* * *} P<0.001$, and the cut-off point is 0.500 .

As the table shows, the bankruptcy classification model at step 1 (Model 1) includes all variables in the bankruptcy measurement model, where the model deviance between the observed and predicted values of the data is 17.07, and 97\% of the variation in the data is explained; the corresponding Type I, Type II, and overall correct classification rates are $97.80 \%, 100.00 \%$, and $98.90 \%$. 
At step 2, the bankruptcy classification model (Model 2), excluding the RE/TA variable from Capital Structure and Solvency, explains $97 \%$ of the variation in thedata, which is the same as that of Model 1. The model deviance slightly increases to 17.13; however, the respective Type I, Type II, and overall correct classification rates are $97.80 \%, 100.00 \%$, and $98.90 \%$, which are not affected.

The deleted variables form steps 3 to 13 include OCF/IP, OCF/TA, RE/TA, EBIT/I, EBIT/FA, EBIT/TA, EBIT/CL, EBIT/TL, GFA, GTA, MVE/BVE, and MC/TD. At step 13, the bankruptcy classification model (Model 13) is composed of OCF/S, EBIT/FC, GTanA, and P/E that are all negatively related to bankruptcy, suggesting that a company is more likely to fail if it has lower OCF/S, EBIT/FC, GTanA, and P/E. Model 13 is able to explain $96 \%$ of the variation in the data, where the model deviance is 23.08. Although the model explains $1 \%$ less of the variation in the data and has relatively more model deviance than does Model 1 with all variables, the respective Type I, Type II, and overall correct classification accuracy of Model 13are 97.80\%, 100.00\%, and 98.90\%, which are as same as Model 1's.

Table 5 reports the multicollinearity diagnostics of Model 13. As seen in the table, the condition numbers of all the eigenvalues are smaller than 30, suggesting that multicollinearity does not exist in the model (Belsley et al. 1980). Consequently, we conclude Model 13 as the optimum bankruptcy classification model one year before bankruptcy.

Table 5: Multicollinearity diagnostics of Model 13

\begin{tabular}{ccccccc}
\hline \multirow{2}{*}{$\begin{array}{r}\text { Principal } \\
\text { Component }\end{array}$} & \multirow{2}{*}{$\begin{array}{c}\text { Eigenval } \\
\text { ue }\end{array}$} & $\begin{array}{c}\text { Conditio } \\
\text { nNumber }\end{array}$ & OCF/S & $\begin{array}{c}\text { EBIT/ } \\
\text { FC }\end{array}$ & GTanA & P/E \\
\hline 1 & \multirow{2}{*}{2.01606} & \multirow{2}{*}{1.00000} & 0.0678 & 0.0971 & 0.0818 & 0.0858 \\
& & & 0 & 3 & 9 & 7 \\
2 & 1.01801 & \multirow{2}{*}{1.40726} & 0.3066 & 0.0377 & 0.2004 & 0.1553 \\
& & & 6 & 8 & 2 & 7 \\
3 & 0.60560 & \multirow{2}{*}{1.82456} & 0.0394 & 0.0314 & 0.7176 & 0.4624 \\
& & & 4 & 0 & 9 & 3 \\
4 & 0.36033 & 2.36539 & 0.5861 & 0.8336 & 0.0000 & 0.2963 \\
& & & 0 & 9 & 1 & 3 \\
\hline
\end{tabular}

${ }^{\mathrm{a}}$ All financial variables are transformed by $T(X)_{i, k}=\exp \left(X_{i, k}\right) /\left(1+\exp \left(X_{i, k}\right)\right)$.

\subsection{Classification accuracy}

The left-hand side of Table 6summarizes the in-sample and out-of-sample classification accuracy of Model 13 oneyear period before bankruptcy. As the table shows, the respective Type I, Type II, and overall in-sample classification accuracy of the model are $97.80 \%$ (90 of 92 correctly classified), 100.00\% (92 of 92 correctly classified), and $98.90 \%$ (182 of 184 correctly classified), whist those out-of-sample classification accuracy of the model are $91.89 \%$ (34 of 37 correctly classified), $97.30 \%$ (36 of 37 correctly classified), $94.59 \%$ (4 of 74 correctly classified).

Table 6: Classification validation results of the out-of-sample data of 74 bankrupt and non-bankrupt firms

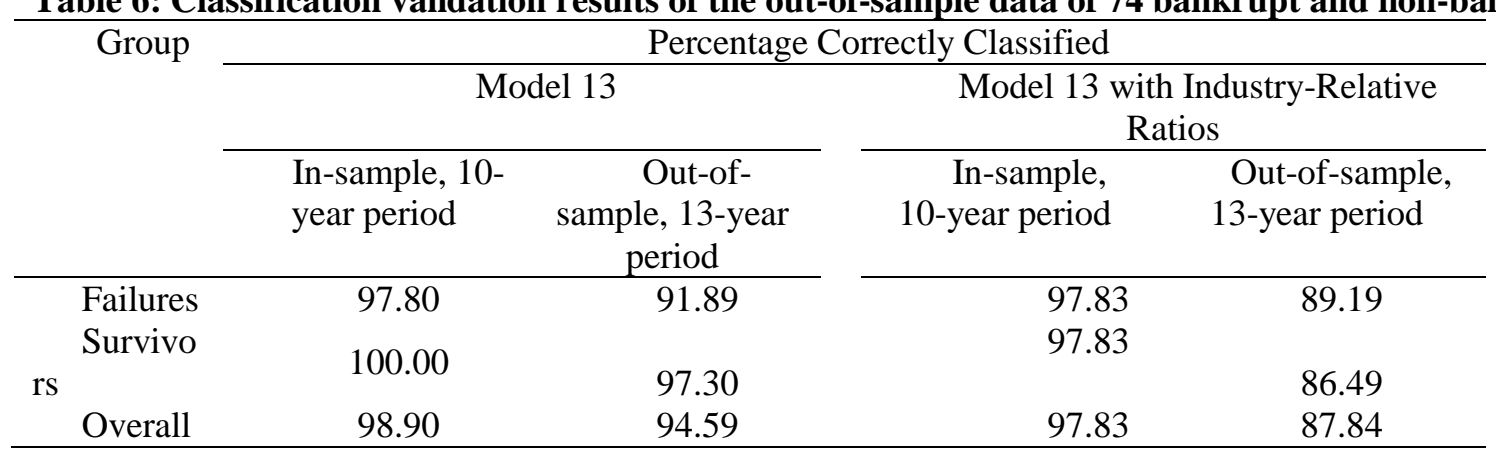

The results of this out-of-sample test are indeed impressive, given a wide cross-section of industrial sectors, and comparable to previous bankruptcy studies in the United States and elsewhere. Specifically, the type I accuracy moderately decreases $5.91 \%$ (from $97.80 \%$ to $91.89 \%$ ), whilst the type II and overall accuracy slightly decreases $2.7 \%$ (from $100.00 \%$ to $97.30 \%$ ) and $4.31 \%$ (from $98.90 \%$ to $94.59 \%$ ), respectively, indicating that the classification model is not sensitive to differential industry effects and time variations.

Whilst prior studies (e.g., Altman and Izan, 1983; Izan, 1984; Platt and Platt, 1990, 1991) propose using IRRs to control for industry and time variations, they demonstrate significantly better out-of-sample classification results for corporate bankruptcy models using IRRS than raw financial ratios. To evaluate how well our model decouples from differential industry effects and data instability over time, we performed industry-relative analysis. The model specification was not changed and, thus, the results are comparable. 
The right-hand side of Table 6 reports the classification results of the model using IRRs.The respective Type I, Type II, and overall in-sample (out-of-sample) classification accuracy are 97.83\% (89.19\%), 97.83\% (86.49\%), and $97.83 \%(87.84 \%)$. The results show that the overall in-sample classification accuracy with IRRsis slightly lower, but the difference between in-sample and out-of-sample classification results with IRRs is considerably larger. This suggests that the combined $T(X)_{i, k}$ and measurement approach is sufficiently robust so as to develop a relatively stable model specification for bankruptcy forecasting.

In order to further assess predictive performance of Model 13, this study compares its results with the forecasting results from a similar study by Barboza et al. (2017). They combine Altman's (1968) Z-score model with six financial indicators to develop bankruptcy-prediction model based on Machine learning models, producing an 87\% classification accuracy. In contrast, the average out-of-sample classification accuracy of Model 13 is $94.59 \%$. This result indicates that Model 13 outperforms the bankruptcy forecasting model of Barboza et al. (2017).

\section{Conclusion}

This study develops a corporate bankruptcy classification model from a sample of 258 bankrupt and non-bankrupt companies, covering a period of 23 years. Instead of depending on traditional ratios, it uses a simple exponential function-based algorithm to improve the stability of financial data. Improved stability of the financial data is developed to a bankruptcy performance-measurement model using confirmatory factor analysis, which is then refined to a four variable, logit bankruptcy model. The model shows high classification accuracy and relatively small differences in classification rates between in-sample and out-of-sample as compared to industry-relative analysis. The model appears to be robust across a broad range of firms and industries. As such, the combined $T(X)_{i, k}$ and measurement approach appears to be especially appealing for bankruptcy models where companies represent a wide cross-section of industries.

\section{References}

Agarwal, V., \&Taffler, R. J.(2008). Comparing the performance of market-based andaccounting-based bankruptcy prediction models. Journal of Banking and Finance32(8), 1541-1551.

Akbar, A., Akbar, M., Tang, W., \& Qureshi, M.A. (2019). Is bankruptcy risk tied to corporate life-cycle? Evidence from Pakistan. Sustainability, 11(3), 1-22.

Altman, E. I. 1968. Financial ratios, discriminant analysis and the prediction of corporate bankruptcy.Journal of Finance23(4),589-609.

Altman, E. I., Haldeman, R. G., \&Narayanan, P. (1977). ZETATM analysis: A new model to identify bankruptcy risk of corporations. Journal of Banking and Finance 1(1),29-54.

Altman, E. I., \&Izan, H. Y. (1983). Identifying corporate distress in Australia: An industry relative analysis. Australian Graduate School of Management.

Arena, M.(2008). Bank failures and bank fundamentals: A comparative analysis of Latin America and East Asia during the nineties using bank-level data. Journal of Banking and Finance 32(2), 299-310.

Barboza, Flavio, Herbert Kimura, \& Edward Altman. (2017). Machine learning models and bankruptcy prediction." Expert Systems with Applications 83, 405-417.

Beaver, W. H.(1966). Financial ratios as predictors of failure. Journal of Accounting Research, 4, 71-111.

Bentler, P. M.(1990). Comparativefitindexesinstructuralmodels.Psychological Bulletin107(2), 238-246.

Belsley, D. A.,Kuh, E.,Welsch, R. E. (1980). Regression Diagnostics.New York : John Wiley \& Son.

Charitou, A., Neophytou, E. \&Charalambous, C.(2004). Predicting corporate failure: Empirical evidence for the UK. European Account Review13(3), 465-497.

Dambolena, I. G., Khoury, S. J.(1980). Ratio stability and corporate failure.Journal of Finance35(4),1017-1026.

Foreman, R. D.(2003). A logistic analysis of bankruptcy within the US local telecommunications industry. Journal of Economics and Business 55(2),135-166.

Fornell, C., \& Larcker, D. F.(1981). Evaluating structural equation model with unobservable variables and measurement error.Journal of Marketing Research18(1), 39-50.

Frohlich, M. T.(2002).E-integrationinthesupplychain: barriers andperformance.Decision Sciences 33(4), 537-56

Gavurova, B., Packova, M., Misankova, M., \& Smrcka, L. (2017). Predictive potential and risks of selected bankruptcy prediction models in the Slovak business environment. Journal of Business Economics and Management 18(6), 1156-1173.

Harrington, D. (2008). Confirmatory Factor Analysis. New York, NY: Oxford University Press.

Izan, H.Y. 1984. Corporate distress in Australia.Journal of Banking and Finance 8(2),303-20.

Kim,Y., \&Nabar, S. (2007).Bankruptcy probability changes and the differential informativeness of bond upgrades and downgrades.Journal of Banking and Finance31(12),3843-3861.

Kline, R. B. (2010). Principlesandpracticeofstructuralequationmodeling. New York: The Guilford Press. 
Kwak, W., Shi, Y.,\&Kou, G.(2012). Bankruptcy prediction for Korean firms after the 1997financial crisis: Using a multiple criteria liner programming data mining approach. Review of Quantitative Finance and Accounting 38(4), 441-453.

Li, M. Y. L., \&Miu, P. (2010). A hybrid bankruptcy prediction model with dynamic loadings on accounting-ratiobased and market-based information: A binary quantile regression approach. Journal of Empirical Finance 17(4), 818-833.

Merton, R. C. (1974). On the pricing of corporate debt: The risk structure of interest rates. Journal of Finance 29, 449-470.

Ohlson, J. (1980). Financial ratios and the probabilistic prediction of bankruptcy. Journal of Accounting Research 18(1), 109-131.

Otley, D. (1999). Performance Management: A Framework for Management Control Systems Research. Management Accounting Research 10(4), 363-382.

Platt, H. D.,\& Platt, M. B. (1990). Development of a class of stable predictive variables: The case of bankruptcy prediction. Journal of Business Finance and Accounting 17(1), 31-51.

Platt, H. D., \&Platt., M. B. (1991). Anoteontheuseofindustry-relativeratiosinbankruptcyprediction. Journal of Banking and Finance 15(6), 1183-1194.

Pompe, P. P., \&Bilderbeek, J. (2005). Thepredictionofbankruptcyofsmall-andmedium-sizedindustrial firms. Journal of Business Venturing20(6), 847-868.

Table 1: Taxonomy of financial variables as bankruptcy-predictor attributes, Kolmogorov-Smirnov tests, and Mann-Whitney $U$ tests

\begin{tabular}{|c|c|c|}
\hline Financial Variables & $\begin{array}{l}\text { Kolmogorov- } \\
\text { Smirnov Statistic } \\
N=184\end{array}$ & $\begin{array}{c}\text { Mann- } \\
\text { Whitney U } \\
\text { Standardized } \\
\text { Statistic N=184 }\end{array}$ \\
\hline $\begin{array}{l}\text { Cash Flow } \\
\text { Cash flow to total assets (CF/TA) } \\
\text { Operating cash flow to sales (OCF/S) } \\
\text { Operating cash flow to net income (OCF/NI) } \\
\text { Operating cash flow to interest payments(OCF/IP) } \\
\text { Operating cash flow to current liabilities (OCF/CL) } \\
\text { Operating cash flow to long-term liabilities (OCF/LL) } \\
\text { Operating cash flow to total liabilities (OCF/TL) } \\
\text { Operating cash flow to net worth (OCF/NW) } \\
\text { Operating cash flow to total assets(OCF/TA) } \\
\text { Capital Structure and Solvency } \\
\text { Current liabilities to common equity (CL/CE) } \\
\text { Long-term liabilities to common equity (LL/CE) } \\
\text { Total liabilities to common equity (TL/CE) } \\
\text { Current assets to common equity (CA/CE) } \\
\text { Total assets to common equity (TA/CE) } \\
\text { Degree of operating leverage (EOL) } \\
\text { Degree of financial leverage (DFL) } \\
\text { Degree of combined leverage (DCL) } \\
\text { Current liabilities to total liabilities (CL/TL) } \\
\text { Total liabilities to total assets (TL/TA) } \\
\text { Retained earnings to total assets(RE/TA) } \\
\text { Earnings before interest and taxes to interest (EBIT/I) } \\
\text { Earnings before interest and taxes } \\
\text { charges(EBIT/FC) } \\
\text { Short Term Liquidity } \\
\text { Cash to current liabilities (C/CL) } \\
\text { Quick assets to total assets (QA/TA) } \\
\text { Quick assets to current liabilities (QA/CL) } \\
\text { Current assets to total assets (CA/TA) } \\
\text { Current liabilities to current assets (CL/CA) } \\
\text { Working capital (WC) } \\
\text { Working capital to total assets (WC/TA) } \\
\text { Profitability Performance } \\
\text { Net income to sales (AI/S) }\end{array}$ & 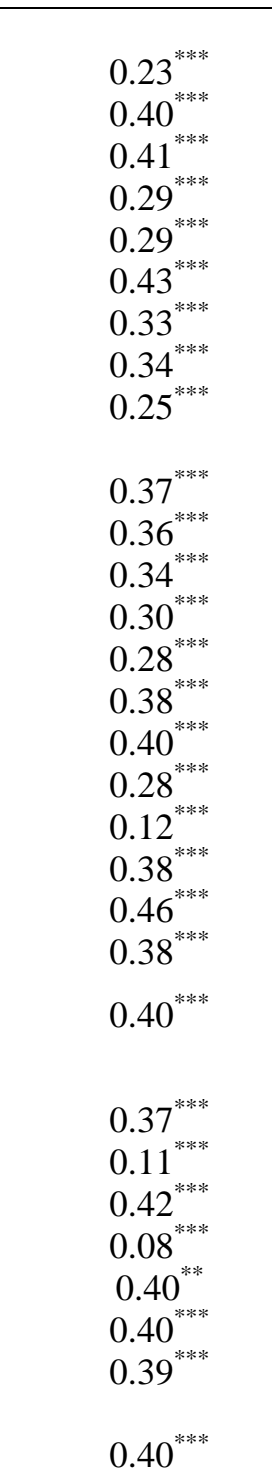 & $\begin{array}{c}-1.10 \\
-0.79 \\
-0.77 \\
-3.71^{* * *} \\
-3.36^{* * *} \\
-7.10^{\text {*** }} \\
-5.26^{\text {*** }} \\
-5.29^{\text {*** }} \\
-0.98^{* * *} \\
-5.64^{\text {*** }} \\
-6.98^{\text {*** }} \\
-7.99^{\text {*** }} \\
-7.97^{\text {*** }}\end{array}$ \\
\hline
\end{tabular}




Earnings before interest and taxes to fixed assets
$\begin{gathered}\text { (EBIT/FA) } \\ \text { Earnings before interest and taxes to total assets }\end{gathered}$
$\begin{aligned} & \text { (EBIT/TA) } \\ & { }^{*} P<0.05,{ }^{* *} P<0.01 \text {, and }{ }^{* * *} P<0.001 .\end{aligned}$

Table 1: Continued

\begin{tabular}{|c|c|c|}
\hline Financial Ratios & $\begin{array}{c}\text { Kolmogorov- } \\
\text { Smirnov Statistic } \\
\text { N=184 }\end{array}$ & $\begin{array}{c}\text { Mann- } \\
\text { Whitney U } \\
\text { Standardized } \\
\text { Statistic N=184 }\end{array}$ \\
\hline $\begin{array}{l}\text { Earnings before interest and taxes to current liabilities } \\
\text { (EBIT/CL) }\end{array}$ & $0.37^{* * *}$ & $-6.53^{* * *}$ \\
\hline $\begin{array}{l}\text { Earnings before interest and taxes to total } \\
\text { liabilities(EBIT/TL) }\end{array}$ & $0.33^{* * *}$ & $-6.22^{* * *}$ \\
\hline Income before extraordinary items to fixed assets (IBEI/FA) & $0.46^{* * * *}$ & $-4.11^{* * * * *}$ \\
\hline Income before extraordinary items to total assets(IBEI/TA) & $0.40^{* * *}$ & $-6.23^{* * * *}$ \\
\hline $\begin{array}{l}\text { Income before extraordinary items to current } \\
\text { liabilities(IBEI/CL) }\end{array}$ & $0.45^{* * *}$ & $-3.32^{* * * *}$ \\
\hline $\begin{array}{l}\text { Income before extraordinary items to net worth(IBEI/NW) } \\
\text { Operating Performance }\end{array}$ & $0.54^{* * *}$ & -0.62 \\
\hline Sales to inventory $(\mathrm{S} / \mathrm{I})$ & $0.40^{* * * * *}$ & -1.91 \\
\hline Sales to quick assets (S/QA) & $0.26^{\text {**** }}$ & -1.74 \\
\hline Sales to current assets (A/CA) & $0.24^{* \text { *at }}$ & -0.41 \\
\hline Sales to fixed assets (S/FA) & $0.43^{* * * *}$ & -1.00 \\
\hline Sales to total assets (S/TA) & $0.29^{* * *}$ & 0.01 \\
\hline Sales to current liabilities (S/CL) & $0.44^{* * * *}$ & $-4.38^{* * *}$ \\
\hline Sales to total liabilities (S/TL) & $0.31^{* * * *}$ & $-3.82^{* * * * *}$ \\
\hline Current liabilities to sales (CL/S) & 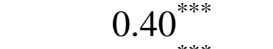 & $-6.37^{* * * * *}$ \\
\hline Growth in gross income (GGI) & $0.31^{* * *}$ & $-5.99^{* * * *}$ \\
\hline Growth in total liabilities (GTL) & $0.44^{* * *}$ & $-3.16^{* *}$ \\
\hline Growth in accounts receivable (GAR) & $0.32^{* * *}$ & $-3.59^{* * * * *}$ \\
\hline Growth in inventory (GI) & $0.15^{* * *}$ & $-7.00^{* * * *}$ \\
\hline Growth in fixed asset(GFA) & $0.46^{* * * *}$ & $-7.36^{* * * *}$ \\
\hline Growth in tangible assets(GTanA) & $0.45^{* * *}$ & $-7.21^{* * * *}$ \\
\hline Growth in property, plant and equipment (GPPE) & $0.27^{\text {**** }}$ & $-7.61^{* * * * *}$ \\
\hline Growth in total assets(GTA) & $0.46^{\text {wat }}$ & -7.00 \\
\hline Market & & \\
\hline Price-earnings ratio $(\mathrm{P} / \mathrm{E})$ & $0.37_{* * * *}^{* * *}$ & $-11.44^{* * * *}$ \\
\hline Common dividends (CD) & $0.44^{* * * *}$ & $-9.04^{* * *}$ \\
\hline Common dividends to outstanding shares (CD/OS) & $0.41^{* * * *}$ & $-9.75^{* * * *}$ \\
\hline Market value of common stock (MVCS) & $0.36_{* * * * *}^{* * *}$ & $-6.42_{* * * * *}^{* * *}$ \\
\hline Market capitalization (MC) & $0.38^{\text {**** }}$ & $-3.61^{* * * * *}$ \\
\hline $\begin{array}{l}\text { Market value of equity to book value of total debt } \\
\text { (MVE/BVTD) }\end{array}$ & $0.44^{* * *}$ & $-2.41^{*}$ \\
\hline Market value of equity to book value of equity (MVE/BVE) & $0.43^{* * *}$ & $-7.77^{* * * * *}$ \\
\hline Market capitalization to total $\operatorname{debt}(\mathrm{MC} / \mathrm{TD})$ & $0.44^{* * *}$ & $-4.22^{* * * *}$ \\
\hline
\end{tabular}

${ }^{*} P<0.05,{ }^{* *} P<0.01$, and ${ }^{* * * *} P<0.001$. 
Table 2: Analysis of data stability after $T(X)_{i, k}$ transformation against industry-relative ratios (IRRs) using the in-sample data of 184 bankrupt and non-bankrupt companies

Source

Panel A

SDs of 48 variables' IRRs

SDs of 48 variables after $T(X)_{i, k}$ transformation

Median SD difference between IRRs and after $T(X)_{i, k}$ transformation

\section{Panel B}

SEs of 48 variables' IRRs

SEs of 48 variables after $T(X)_{i, k}$ transformation

Median SE difference between IRRs and after $T(X)_{i, k}$ transformation

\begin{tabular}{cccr}
\hline Me & Minim & Maximu & Kolmogorov- \\
an & um & $\mathrm{m}$ & Smirnov Statistic \\
\hline
\end{tabular}

$\begin{array}{cccc}32 . & 1.11 & 779.35 & 0.400^{* * *} \\ 83 & & & \\ 0.1 & 0.07 & 0.43 & 0.212^{* * *} \\ 9 & & \end{array}$

${ }^{*} P<0.05,{ }^{* *} P<0.01$, and ${ }^{* * * *} P<0.001$.

Table 3: Squared correlations, average variance extracted, and composite reliability of the bankruptcy performance-measurement model

\begin{tabular}{lrrr}
\hline Variable & Cash Flow & $\begin{array}{c}\text { Capital } \\
\text { Structure and } \\
\text { Solvency }\end{array}$ & $\begin{array}{c}\text { Profitability } \\
\text { Performance } \\
\text { Performance }\end{array}$ \\
\hline Cash Flow & 1 & & \\
Capital Structure and Solvency & 0.58 & 0.57 & 1 \\
Profitability Performance & 0.45 & 0.09 & 0.04 \\
Operating Performance & 0.04 & 0.50 & 0.32 \\
Market & 0.32 & 0.72 & 0.81 \\
Average Variance Extracted & 0.61 & 0.74 & 0.50 \\
Composite Reliability & 0.74 & & 0.81 \\
\hline
\end{tabular}

Table 4; Bankruptcyclassification models created with multivariate logistic-regression analyses with backward elimination

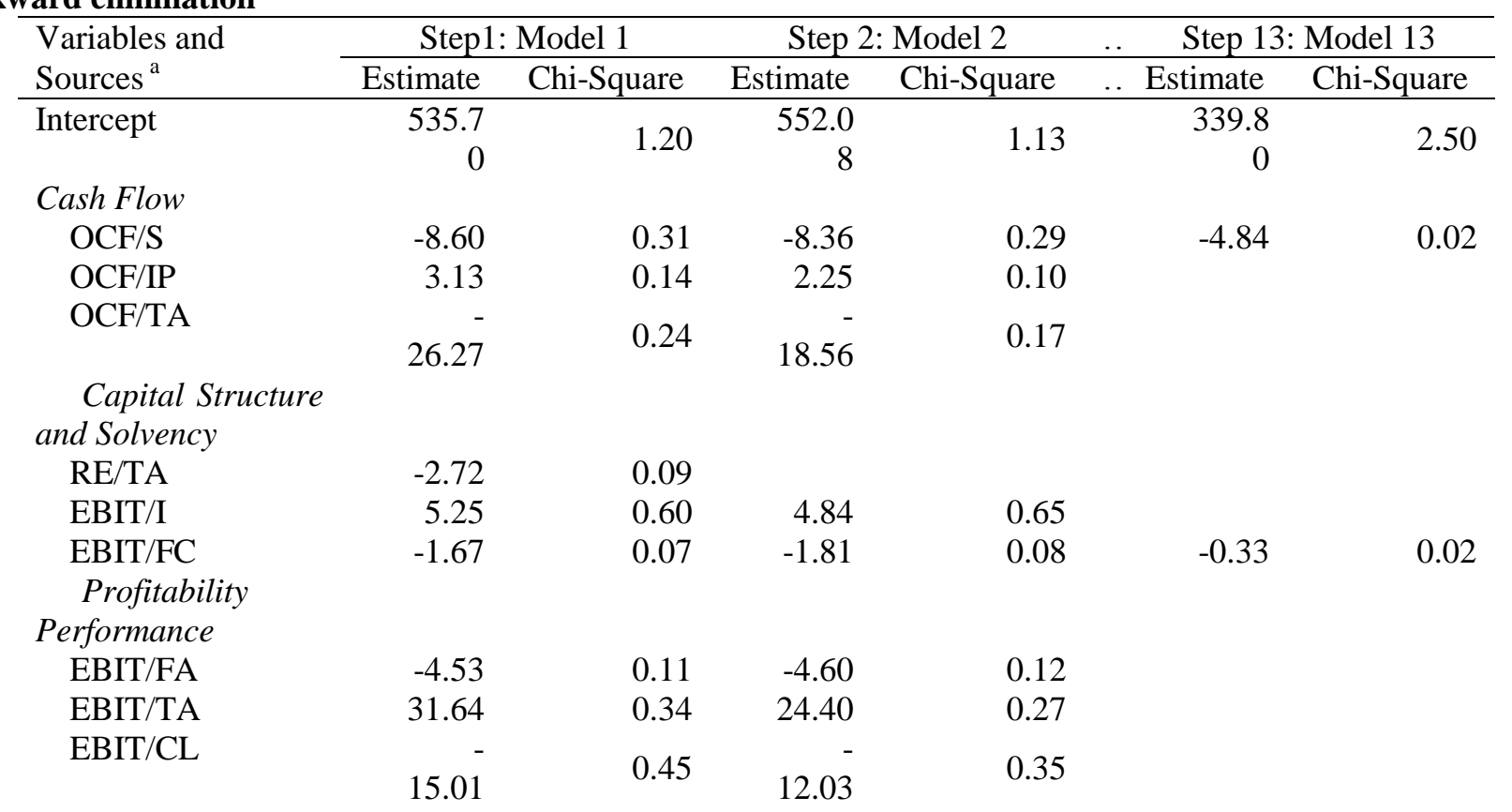




\begin{tabular}{|c|c|c|c|c|c|c|}
\hline $\begin{array}{l}\text { EBIT/TL } \\
\text { Operating }\end{array}$ & 16.31 & 0.40 & 12.28 & 0.28 & & \\
\hline \multicolumn{7}{|l|}{ Performance } \\
\hline GFA & 35.19 & 0.67 & 31.60 & 0.57 & & \\
\hline GTanA & $51.10^{-}$ & 0.98 & 49.83 & 0.93 & -5.40 & 1.20 \\
\hline $\begin{array}{l}\text { GTA } \\
\text { Market }\end{array}$ & 7.91 & 0.15 & 10.31 & 0.32 & & \\
\hline $\mathrm{P} / \mathrm{E}$ & 544.55 & 1.22 & 561.37 & 1.16 & 343.81 & 3.64 \\
\hline MVE/BVE & -3.97 & 0.15 & -4.27 & 0.18 & & \\
\hline $\mathrm{MC} / \mathrm{TD}$ & 12.74 & 1.12 & 13.51 & 1.25 & & \\
\hline -2 Log likelihood & 17.07 & & 17.13 & & 23.08 & \\
\hline Nagelkerke $R^{2}$ & 0.97 & & 0.97 & & 0.96 & \\
\hline Type I Accuracy & $\begin{array}{r}97.80 \\
\%\end{array}$ & & $\begin{array}{r}97.80 \\
\%\end{array}$ & & $\begin{array}{r}97.80 \\
\%\end{array}$ & \\
\hline Type II Accuracy & $\begin{array}{r}100.0 \\
0 \%\end{array}$ & & $\begin{array}{r}100.0 \\
0 \%\end{array}$ & & $\begin{array}{r}100.0 \\
0 \%\end{array}$ & \\
\hline Overall Correct & $\begin{array}{r}98.90 \\
\%\end{array}$ & & $\begin{array}{r}98.90 \\
\%\end{array}$ & & $\begin{array}{r}98.90 \\
\%\end{array}$ & \\
\hline
\end{tabular}

${ }^{\mathrm{a}}$ All financial variables are transformed by $T(X)_{i, k}=\exp \left(X_{i, k}\right) /\left(1+\exp \left(X_{i, k}\right)\right)$.

${ }^{*} P<0.05,{ }^{* *} P<0.01$, and ${ }^{* * * *} P<0.001$, and the cut-off point is 0.500 .

Table 5: Multicollinearity diagnostics of Model 13

\begin{tabular}{ccccccc}
\hline $\begin{array}{r}\text { Principal } \\
\text { Component }\end{array}$ & \multirow{2}{*}{$\begin{array}{c}\text { Eigenval } \\
\text { ue }\end{array}$} & \multirow{2}{*}{$\begin{array}{c}\text { Conditio } \\
\text { nNumber }\end{array}$} & OCF/S & EBIT/ & GTanA & P/E \\
\cline { 5 - 7 } & \multirow{2}{*}{2.01606} & \multirow{2}{*}{1.00000} & 0.0678 & 0.0971 & 0.0818 & 0.0858 \\
& & & 0 & 3 & 9 & 7 \\
2 & \multirow{2}{*}{1.01801} & \multirow{2}{*}{1.40726} & 0.3066 & 0.0377 & 0.2004 & 0.1553 \\
& & & 6 & 8 & 2 & 7 \\
3 & \multirow{2}{*}{0.60560} & \multirow{2}{*}{1.82456} & 0.0394 & 0.0314 & 0.7176 & 0.4624 \\
& & & 4 & 0 & 9 & 3 \\
4 & \multirow{2}{*}{0.36033} & \multirow{2}{*}{2.36539} & 0.5861 & 0.8336 & 0.0000 & 0.2963 \\
& & & 0 & 9 & 1 & 3 \\
\hline
\end{tabular}

${ }^{\mathrm{a}}$ All financial variables are transformed by $T(X)_{i, k}=\exp \left(X_{i, k}\right) /\left(1+\exp \left(X_{i, k}\right)\right)$.

Table 6: Classificationvalidation results of the out-of-sample data of 74 bankrupt and non-bankrupt firms

\begin{tabular}{|c|c|c|c|c|c|}
\hline \multirow{3}{*}{\multicolumn{2}{|c|}{ Group }} & \multicolumn{4}{|c|}{ Percentage Correctly Classified } \\
\hline & & \multicolumn{2}{|c|}{ Model 13} & \multicolumn{2}{|c|}{$\begin{array}{c}\text { Model } 13 \text { with Industry-Relative } \\
\text { Ratios }\end{array}$} \\
\hline & & $\begin{array}{l}\text { In-sample, } 10- \\
\text { year period }\end{array}$ & $\begin{array}{c}\text { Out-of- } \\
\text { sample, } 13 \text {-year } \\
\text { period }\end{array}$ & $\begin{array}{l}\text { In-sample, } \\
\text { 10-year period }\end{array}$ & $\begin{array}{l}\text { Out-of-sample, } \\
\text { 13-year period }\end{array}$ \\
\hline \multirow{2}{*}{\multicolumn{2}{|c|}{$\begin{array}{l}\text { Failures } \\
\text { Survivo }\end{array}$}} & 97.80 & 91.89 & 97.83 & 89.19 \\
\hline & & 100.00 & 9730 & 97.83 & 8649 \\
\hline 15 & Overall & 98.90 & 94.59 & 97.83 & 87.84 \\
\hline
\end{tabular}




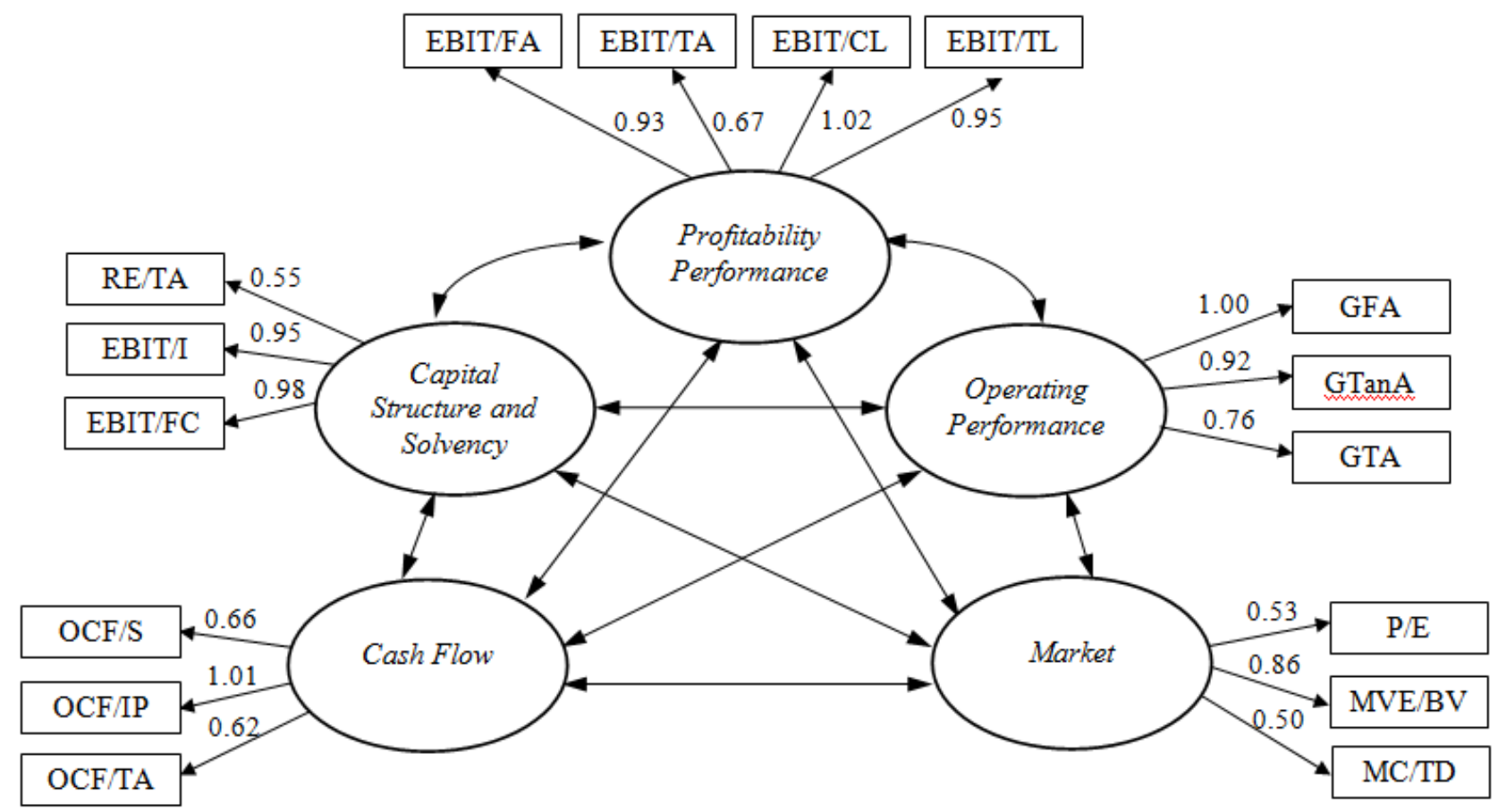

Figure 1: Performance-measurement model for bankruptcy classification 